\title{
Turizm Rehberliği Öğrencilerinin İletişim Becerileri Üzerine Bir Araştırma: Afyon Kocatepe Üniversitesi Örneği
}

\section{A Study on Tourism Guidance Students' Communication Skills: The Case of Afyon Kocatepe University}

\author{
Arş. Gör. Ali KABAKULAK \\ Afyon Kocatepe Üniversitesi, Turizm Fakültesi, Türkiye \\ Afyon Kocatepe University, Faculty of Tourism, Turkey
}

E-Mail: alikabakulak@aku.edu.tr

\section{$\ddot{O} z$}

Amaç ve Önem: Bu çalışmanın amacı turizm rehberliği bölümü öğrencilerinin iletişim düzeylerinin belirlenmesidir. Afyon Kocatepe Üniversitesinde lisans eğitimi gören turizm rehberliği öğrencilerinin iletişim beceri düzeylerinin belirlenmesine yönelik daha önce herhangi bir çalışma yapılmamıştır. $\mathrm{Bu}$ kapsamda turizm rehberliği öğrencilerinin iletişim düzeylerinin belirlenmesi ve turist rehberliği mesleğini icra edecek kişilerin iletişimlerinin güçlendirmesine katkı sağlaması açısından bu çalışma önemlidir.

Yöntem: Araştırma kapsamında tam sayım yöntemi kullanılarak 231 öğrenciden anket tekniği ile veriler elde edilmiştir. İletişim Becerileri Envanteri (İBE), üniversite öğrencilerinin sahip oldukları iletişim beceri düzeylerini değerlendirmek amacıyla Ersanlı ve Balcı (1998) tarafindan geliştirilen ölçeğin kullanıldığı araştırmada veriler Eylül-Kasım 2018 tarihleri arasında elde edilmiştir. Araştırmada tanımlayıcı analizler (sıklık, yüzde, aritmetik ortalama, standart sapma teknikleri), güvenirlik (Cronbach's Alpha kat sayısı) analizi, t-testi ve Varyans (Anova) analizleri gerçekleştirilmiştir.

Bulgular: Araştırmadan çıkan sonuçlara göre, turizm rehberliği öğrencilerinin iletişim becerilerinin yüksek olduğu belirlenmiştir. Ayrıca yapılan t-testi sonucunda turizm rehberliği öğrencilerinin iletişim beceri düzeylerinin diğer bireysel özelliklerine (cinsiyet, medeni hal, öğrenim durumu (normal ve ikinci öğretim), bölümü isteyerek seçme) göre incelendiğinde öğrencilerin iletişim beceri düzeyleri anlamlı bir farklılık göstermediği belirlenmiştir.

Sınırlılıklar: Yalnızca nicel araştırma tekniklerinin tercih edilmesi, uygulama kapsamında araştırma örnekleminin 231 kişi ile sınırlandırılması, araştırmanın sadece belirli bir dönemde gerçekleştirilmesi, benzer araştırma sayısının azlığı sebebi ile araştırma sonuçlarını karşılaştırma imkânın az olması bu araştırmanın temel sınırlılıklarını teşkil etmektedir.

Anahtar Kelimeler: İletişim, iletişim becerileri, turizm, turizm rehberliği öğrencileri.

Makale Türü: Araştırma

\begin{abstract}
Purpose and Importance: The aim of this study is to determine the communication level of tourism guidance students. Studies have not been conducted to determine the communication skill levels of tourism guidance students undergoing undergraduate education at Afyon Kocatepe University. In this context, this study is important in terms of determining the communication levels of tourism guidance students and contributing to the strengthening of the communication of the people who will perform the tourism guidance profession.
\end{abstract}

Attf için (to cite); Kabakulak, A. (2019). Turizm Rehberliği Öğrencilerinin İletişim Becerileri Üzerine Bir Araştırma: Afyon Kocatepe Üniversitesi Örneği, Turist Rehberliği Dergisi, 2(1), 18-30. 


\section{IIIII)}

Turist Rehberliği Dergisi (TURED) \& Yıl. 2019, Cilt. 2, Sayı. 1

Journal of Tour Guiding (JOTOG) \& Year. 2019, Volume. 2, Issue. 1

Methodology: In the scope of the research, data were obtained from the students of Afyon Kocatepe University Tourism Guidance Department by using the total population sampling method and questionnaire technique from 231 students. The Communication Skills Inventory (HCI) was used between September and November 2018 in a survey which was developed by Ersanlı and Balc1 (1998) in order to evaluate the communication skill levels of university students. After applying the obtained data, descriptive analyzes (frequency, percentage, arithmetic mean, standard deviation techniques), reliability (Cronbach's Alpha coefficient) analysis, t-test and Variance (Anova) analysis were performed.

Findings: According to the results, it was determined that the communication skills of tourism guidance students were high. In addition, as a result of the t-test, when the communication skills levels of tourism guidance students were examined according to their other individual characteristics (gender, marital status, educational status (normal and secondary education), willingly choosing the department), it was determined that there was not significant difference between the related variables and the communication skill levels of the students.

Limitations: The main limitations of this study are the fact that only quantitative research techniques are preferred, the scope of the study is limited to 231 people, the research is conducted only in a certain period of time, and the possibility of comparing the research results due to the small number of similar studies.

Keywords: Communication, communication skills, tourism, tourism guidance students.

Paper Type: Research

\section{Giriş}

21. yüzyıl iletişim çağı olarak adlandırılmaktadır. Dolayısıyla ülkeler, organizasyonlar, insanlar varlıklarını sürdürebilmek için birbirleriyle iletişim kurmak zorundadırlar. Son yıllarda internetin yaygınlaşması, buna bağlı olarak da insanlar arasında bilgi alışverişinin sağlanması iletişimi daha önemli bir noktaya taşımıştır. İletişim, insanlar için hayati öneme sahiptir. Dolayısıyla sosyal bir varlık olan insanın yaşadığı çevrede ya da çalıştı̆̆ yerde var olabilmesi çevresiyle kuracağı iletişime bağlıdır. Turist rehberleri, kültür aracı olarak ve turistler ile yerel halk arasında iletişim sağlayıcı olarak önemli rol oynamaktadırlar. Turist rehberi yerel halk ve turist arasında kültür yorumcusudur. Turist ile yerel halk arasındaki kültür etkileşiminde kritik bir öneme sahiptir (Tetik, 2006: 23).

Ülkelerin tanıtım elçileri olan turist rehberlerinin taşıması gereken en önemli nitelikler arasında dışadönük kişilik yapısına sahip olma, yabancı dili ve ana dili etkili ve akıcı konuşabilme, beden dilini iyi kullanabilme, iletişim kurma yeterliliklerinin iyi olması, ülkenin yerel ve kültürel değerlerinin doğru bir biçimde tanıtımının yapılması, turistlerde iyi bir ülke imajının bırakılması noktasında özellikle turizm rehberliği eğitimi alırken öğrencilerin iletişim becerilerinin geliştirilmesi ve turistlerin karşısında sunum yaparken doğru tekniklerin kullanılması ve turistleri etkilemesi için öğrencilerin iletişim becerilerini arttırıcı derslere ağırlık verilmesi önem taşımaktadır. Bu nedenle turizm rehberliği eğitimi alan öğrencilerin iletişim becerilerini geliştirmeden turist rehberliği yapması pek mümkün görünmemektedir. İletişim anlamında sorunları olan rehberler/rehber adayları kısa bir zaman içinde işlerini kaybetme riskiyle karşılaşacaktır. Bu nedenle doğru ve etkili iletişim anahtar görevi görüp hem rehber adayları için hem de rehberler için birçok kapının açılmasına vesile olacaktır.

Son yıllarda, turistlerin bireysel tura göre rehber eşlikli turları bazı avantajlarından dolayı daha fazla tercih ettiği dikkat çekmektedir. Bu tercih yönünde turist rehberinin yabancı dil bilgisi, destinasyon bilgisi, turistlerle işletmeler arasındaki aracılık rolü, rehberin zaman yönetimi faktörü gibi turist rehberinin verdiği birçok hizmet etkili olmaktadır. Turistlerin bu

Kabakulak; Turizm Rehberliği Öğrencilerinin İletişim Becerileri Üzerine Bir Araştırma: Afyon Kocatepe Üniversitesi Örneği/A Study on Tourism Guidance Students' Communication Skills: The Case of Afyon Kocatepe University 
hizmetlerden memnun kalması, olumlu algılamaları ve beklentilerini karşılaması turist rehberinin iletişim yeteneğine dayanmaktadır. Bütün turist rehberleri aynı veya benzer hizmetleri vermektedirler. Fakat onları birbirlerinden ayıran ve başarılı olmalarını sağlayan önemli etmenlerden biri de iletişim becerileridir (Büyükkuru, 2015). Çünkü turist rehberlerinin sözlü ya da sözsüz bir biçimde kuracağı iletişim ilk izlenimi oluşturacağından turistler için de yol gösterici olacaktır. Böylelikle turistler alacakları hizmetin nasıl olacağına dair de fikir edinmelerinde iletişim önemli bir rol oynayacaktır.

\section{Kuramsal Çerçeve}

İletişim kavramı, Latincedeki "communis" sözcüğünden türetilmiş olan ve Bat1 dillerinin çoğunda "communication" kavramının karşılı̆g 1 olarak kullanılmaktadır (Mısırlı, 2010: 1). İletişim, mesajın aktarıldığı bir süreçtir. Genel olarak, insan iletişimi sözlü iletişim ve sözsüz iletişim olmak üzere iki türe ayrılabilir. Konuşma ile yapılan iletişim sözlü iletişimdir. Sözlü iletişim insanın doğuştan getirdiği ve zaman içinde öğrendiği dinleme, konușma, okuma ve yazma becerilerini ifade eder. Sözsüz iletișim ise, sözlü iletișim becerilerine ek olarak kişisel konumlandırma, jest ve mimikler, giyim kuşam vb. bütün bunlar sözsüz iletişim kapsamındadır (Hosseyni, 2012: 254). İşleri başarabilmek için kelimeler doğru kullanılmalıdır. Her kelime insanda farklı duygular ve tepkiler ortaya çıkarır. Eğer turist rehberi doğru sözcükleri kullanırsa turistleri hızlı bir şekilde etkileyecektir. Bu nedenle yapamam, mümkün değil vb. gibi olumsuz kelimeleri kullanmaktan kaçınmalıdır. Bir turist rehberi, kelimelerin gücünün ve turistler üzerindeki etkisinin farkında olmalıdır (Yahyai ve Tavili, 2006'dan akt. Hosseyni, 2012). Dolayısıyla turist rehberleri turistlerle etkili iletişim kurmak ve onları etkilemek için kurdukları iletişimlere ve yöntemlerine dikkat etmek durumundadırlar. Turistler, turist rehberleriyle ilk olarak iletişimlerini göz kontağıyla sağlarlar ve turist rehberinin kişiliğine dair ilk izlenimlerini sözsüz iletişim yöntemiyle edinirler. Bu nedenle turist rehberlerinin turistleri etkilemesi ve turistlerde olumlu bir intiba birakmas1 gerekmektedir (Hosseyni, 2012: 254). Turist rehberi mesleği, turizm sektöründeki en önemli mesleklerden biri olarak kabul edilmektedir. Turist rehberleri, hem ülkeyi hem de ülkede yaşayan tüm insanları temsil eder, ülke insanının sahip oldukları tutum, gelenek ve fikirleri yansitırlar (Alshatnawi, 2014: 2). Turist rehberinin turistlerle sözlü iletişimi dikkate alınması gereken ana noktalardan biridir. Rahat konuşma şekli, yüksek sözel beceriler, arzulanan ve uygun dil tonu, turist rehberini hem arkadaşlarıyla hem de turistlerle iyi bir ilişki kurabilir hale getirir. Tur rehberi turistlerle iletişim kurma konusunda önemli bir yeterliliğe sahip olmalıdır. Turistleri kendine çekmeli ve onların güvenini kazanmalı. Turist rehberi yeteneklerini turistlerle bütünleştirerek ve ilişki kurarak gösterir (Pond, 1993). Dolayısıyla turistlerle iyi iletişim kurmak hem turist rehberinin tur boyunca rahat etmesini sağlar hem de çalışlan acentenin bilinirliğine, ekonomisine, müşteri portföyünü arttırmasına katkı sağlar. Ancak kötü bir iletişim kuran turist rehberi, acentenin zarara uğramasına, ülkenin ekonomik açıdan zarar görmesine, turistlerin aldıkları hizmetlerden memnun kalmamasına neden olurlar. İletişim aksaklıklarının giderilmesi için üniversitelerin turizm rehberliği bölümlerinde öğrenim gören öğrencilerin temel derslerin yanında özellikle etkili iletişim ile ilgili derslerin olması ileride ortaya çıkabilecek iletişim sorunlarının önlenmesinde ve doğru ve bilinçli bir iletişimin kurulmasını da ortaya çıkaracaktır.

Daha önce turizm sektöründe hiç çalışmamış, staj yapmamış bir turizm rehberliği bölümü öğrencisinin turist ile rehber arasındaki iletişimin nasıl kurulduğu ve devam ettirildiği, şoför-rehber ilişkisi ya da diğer işletmeler ile rehber arasında iletişimin nasıl kurulması ve sürdürülmesi gerektiğine dair eksikliğin olması çalışma kartının alınmasından ve mesleğe başlanmasından sonra rehber için bir dizi sorunlarla karşılaşmasına ve bu sorunların nasıl çözüme kavuşturulması gerektiğine dair bilgisizlikten dolayı yeni rehber olmuş kişiler için

Kabakulak; Turizm Rehberliği Öğrencilerinin İletişim Becerileri Üzerine Bir Araştırma: Afyon Kocatepe Üniversitesi Örneği/A Study on Tourism Guidance Students' Communication Skills: The Case of Afyon Kocatepe University 


\section{IIIII)}

Turist Rehberliği Dergisi (TURED) \& Yıl. 2019, Cilt. 2, Sayı 1

Journal of Tour Guiding (JOTOG) \& Year. 2019, Volume. 2, Issue. 1

olumsuz mesleki tutumların oluşmasına neden olabilmektedir. $\mathrm{Bu}$ nedenle iletișim becerilerinin geliştirilmesi hem emek yoğun bir sektör olan turizm için hem de doğrudan turistlerin ülkeye varışından ayrilışına kadar turistlerle iletişim kurmak zorunda olun rehberler/rehber adayları için ve ülkelerin kendileri için hayati öneme sahiptir. Ayrıca turizm rehberliği bölümlerinde eğitim alan öğrenciler ve turist rehberlerinin iletişim yeterliliklerinin de araştırmacılar tarafından belirli aralıklarla araştıılması turizm rehberliği öğrencilerinin ve turist rehberlerinin iletişim yeterliliklerini ortaya koyması ve eksikliklerin giderilmesi, daha kaliteli turist rehberliği hizmeti verilmesi açısından önemlidir.

\section{Araştırmanın Amacı ve Önemi}

$\mathrm{Bu}$ çalışmanın amacı, Afyon Kocatepe Üniversitesi’nde lisans düzeyinde turizm rehberliği eğitimi alan öğrencilerin iletişim becerileri düzeylerinin belirlenmesidir. $\mathrm{Bu}$ kapsamda araştırmada şu sorulara yanıt aranmıştır:

Turizm rehberliği alanında lisans düzeyinde eğitim alan öğrencilerin iletişim becerileri ne düzeydedir?

$>$ Öğrencilerin iletişim beceri düzeyleri bazı bireysel özelliklerine (cinsiyet, yaş, öğrenim düzeyi (sınıf), lise türü, bölümü isteyerek seçme, meslek hakkında bilgi sahibi olma ve ikamet edilen yere göre farklıl1k göstermekte midir?

Turist rehberliği mesleği icra edilmesi çok zor bir meslektir. Doğrudan insanla ilgilidir ve doğru bir iletişim kurmayı gerektirir. Bu mesleğin en belirgin özelliklerinden biri de turist rehberlerinin dışadönük bir kişilik yapısına sahip olması ve iletişim kurabilmesidir. Dolayısıyla bir turist rehberinin iletişim kurma becerisi, mesleğin icrasında ve müşteri tatmini yaratılmasında ve hizmetlerin daha kaliteli olmasından da önemli rol oynamaktadır. Bu nedenle sektörde çalışmaya ve turist rehberliği mesleğini icra etmeye hazırlanan turizm rehberliği öğrencilerinin iletişim beceri düzeylerinin belirlenmesi önem taşımaktadır. Afyon Kocatepe Üniversitesinde lisans eğitimi gören turizm rehberliği öğrencilerinin iletişim beceri düzeylerinin belirlenmesine yönelik daha önce herhangi bir çalışma yapılmamıștır. Araştırma bu açıdan önemlidir. Ayrıca turizm rehberliği öğrencilerinin elde edilen bulgular sonucunda iletişim beceri düzeyleri bilgisi elde edilerek, belirlenen/belirlenecek eksikliklerin giderilmesine dönük ilgili taraflara (okul yönetimi, öğrenci, ögretim elamanları vb.) da öneriler getirilmesi mümkün olabilecektir.

\section{Yöntem}

Araştırmada, verilerin toplanmasında anket tekniğinden yararlanılmıştır. Söz konusu anket, iki bölümden oluşturulmuştur. İlk bölümde öğrencilerin bazı kişisel bilgilerinin tespiti amaciyla 10 (öğrencilerin cinsiyet, medeni hal, yaş, öğrenim durumu, öğrenim gördüğü sınıf, mezun olunan okul, bölümü isteyerek seçme, meslek hakkında bilgi, gelinen şehir, ikamet edilen yer) soru yer almaktadır. Anketin ikinci bölümünde, turizm rehberliği öğrencilerinin iletişim beceri düzeylerinin tespitinde "İletişim Becerileri Envanteri" kullanılmıştır. İletişim Becerileri Envanteri (IBBE), üniversite öğrencilerinin sahip oldukları iletişim beceri düzeylerini değerlendirmek amaciyla Ersanlı ve Balcı (1998) tarafından geliştirilen 5'li Likert tipi bir ölçektir. Ölçek 1) hiçbir zaman, 2) nadiren, 3) bazen, 4) genellikle, 5) her zaman biçiminde sıralanmıştır. İlgili ölçek bilişsel (13), duygusal (14) ve davranışsal (14) olmak üzere toplam üç boyuttan oluşmaktadır. Araştırmada kullanılan "İletişim Becerileri Envanterinin" konuyla ilgili bir çok çalışmada da Bingöl ve Demir, 2011; Gaskar ve Özyazıcığlu, 2014; Pelit ve Karaçor, 2015; Tutuk vd., 2002) kullanıldığı görülmüştür. Araştırmada ölçek güvenilirliğini belirlemeye yönelik analizler sonucunda, Cronbach Alpha katsayısının gerek ölçeğin 


\section{IIIII)}

Turist Rehberliği Dergisi (TURED) \& Yı1. 2019, Cilt. 2, Sayı. 1

Journal of Tour Guiding (JOTOG) \& Year. 2019, Volume. 2, Issue. 1

boyutları, gerekse genel itibari ile yüksek sayılabilecek bir değerde olduğu tespit edilmiştir. Ölçeğe ilişkin yapılan güvenirlik analizi sonuçları Tablo 1'de sunulmuştur.

Tablo 1: Anketin Kapsadığı Boyutlar ve Geneline İlişkin Geçerlik ve Güvenirlik Analizi Sonuçları

\begin{tabular}{|l|c|c|c|}
\hline \multicolumn{1}{|c|}{ Faktörler (Boyutlar) } & İfade Sayısı & Varyans Oranı (\%) & Cronbach's Alfa \\
\hline Bilişsel (Zihinsel) İletişim Becerileri & 13 & 53,72 &, 719 \\
\hline Duygusal (Duyuşsal) İletişim Becerileri & 14 & 60,036 &, 854 \\
\hline Davranışsal İletişim Becerileri & 14 & 77,902 &, 794 \\
\hline Genel & $\mathbf{4 1}$ & $\mathbf{6 3 , 8 8 6}$ & $\mathbf{9 0 9}$ \\
\hline
\end{tabular}

Tablo 1'de iletişim becerileri ölçeğinin boyutlarının güvenilirlik analizi sonuçlarına yer verilmiştir. Ölçek üç boyut altında toplanmıştır ve Cronbach's Alpha kat sayıları (0,70-0,90 arası) çıkmıştır. Ortaya çıkan bu değerler ölçeğin yüksek güvenilirliğe sahip olduğunu göstermektedir. Açıklayıcı faktör analizine göre bilişsel iletişim boyutu toplam varyansın \% 53,720'sini, duygusal iletişim boyutu toplam varyansın \% 60,036'sını, davranışsal iletişim boyutu toplam varyansın \% 77,902'sini açıklarken, bu üç boyut toplam varyansın \% 63,886'sını açıklamaktadır.

Araştırmanın evrenini Afyon Kocatepe Üniversitesi'nde lisans düzeyinde turizm rehberliği eğitimi almakta olan öğrenciler oluşturmaktadır. Araştırma 2018 yılı Kasım ayında tam sayım yöntemi uygulanarak gerçekleştirilmiştir. Araştırmada ankete yanıt veren turizm rehberliği öğrencilerinin iletişim beceri düzeylerinin yüzde, frekans, aritmetik ortalama ve standart sapma değerleri verilerek yorumlanmıştır. Turizm rehberliği öğrencilerinin iletişim beceri düzeylerinin bazı bireysel özelliklerine göre farklılık gösterip göstermediğinin tespitinde skewness ve kurtosis kat sayıları kontrol edilmiştir. Söz konusu kat sayıların -2.00 ile +2.00 arasında olması nedeniyle verilerin normal dağıldığı tespit edilmiştir (Kunnan, 1998; Shiel ve Cartwright, 2015: 28). Bununla birlikte ölçekteki 1., 10. ve 22. ifadelerin söz konusu bu sınırların dışında olduğu görülmüştür. Ancak örneklem sayısı büyüdükçe skewness ve kurtosis kat sayılarının değerlerinin azalması söz konusudur. Bu durumda histogram üzerinde dağılımın şekline bakılması daha uygundur (Tabachnick ve Fidell, 2013: 81). Buradan hareketle yapılan değerlendirme sonucunda bu ifadelerin normal dağılım koşuluna uygun olduğu belirlenmiştir.

Verilerin normal dă̆glım gösterdiği tespit edildiğinden testine göre veriler normal dağılım gösterdiği için iki faktörlü değişkenler için (cinsiyet, medeni durum, meslek hakkında bilgi sahibi olma, mesleği isteyerek seçme durumu) t testi, ikiden fazla değişkenler için (yaş, öğrenim düzeyi (sınıf), ikamet edilen yer, gelinen şehir, öğrenim gördüğü lise) tek faktörlü varyans analizi (ANOVA) kullanılmıştır. Sonuçlar araştırmanın amacı doğrultusunda yorumlanarak konuyla ilgili öneriler geliştirilmiştir.

\section{Bulgular ve Tartışma}

Tablo 2'de katılımcıların bazı bireysel özelliklerine ilişkin yüzde ve frekans dağılımları yer almaktadır. Tablo 2'ye göre ankete katılan turizm rehberliği öğrencilerinin \%58,0'i kadın, \%42,0'si erkek olup; \%1,7'si evli, \%98,3'ü bekârdır. Öğrencilerin \% 41,6's1 normal öğretim, \%44,6's1 ise ikinci öğretim öğrencileridir. Öğrencilerin \%42,9'u 1.sınıf, $\% 36,8$ 'i 2 sınıf, \%20,3'ü ise 3 sınıf aralığındadır. Turizm rehberliği öğrencilerinin mezun oldukları okul incelendiğinde \%76,2'si Anadolu lisesi, \%13,0'ü Düz Lise mezunu, \%19,0'nun diğer liselerden, \%2,2'sinin ise Turizm Meslek Lisesi mezunu olduğu bulguları elde edilmiştir. Araştırmaya katılan öğrencilerin rehberlik bölümünü seçme durumları incelendiğinde \%70,1'inin rehberlik bölümünü isteyerek seçtiği, \%29,9'unun ise rehberlik bölümünü istemeyerek seçtiği belirlenmiştir. Öğrencilerin \% 71,4'ünün meslek hakkında bilgisi olduğu, 
Turist Rehberliği Dergisi (TURED) \& Yıl. 2019, Cilt. 2, Sayı. 1

Journal of Tour Guiding (JOTOG) \& Year. 2019, Volume. 2, Issue. 1

\%27,7'sinin de meslek hakkında bilgisi olmadığ saptanmıștır. En fazla Afyon Kocatepe Üniversitesini tercih eden öğrencilerin geldikleri iller değerlendirildiğinde \%7,8'lik oranla İstanbul, İzmir ve Afyonkarahisar'ın ilk sırayı paylaştıkları görülmüştür.

Tablo 2: Katılımcıların Bazı Bireysel Özelliklerine İlişkin Yüzde Frekans Dağılımı

\begin{tabular}{|c|c|c|c|c|c|c|c|}
\hline \multicolumn{2}{|c|}{ Kişisel Bilgiler $(\mathrm{n}=231)$} & $\mathbf{f}$ & $\%$ & \multicolumn{2}{|c|}{ Kişisel Bilgiler $(\mathrm{n}=231)$} & $\mathbf{f}$ & $\%$ \\
\hline \multirow{2}{*}{ Cinsiyet } & Kadın & 134 & 58,0 & \multirow{4}{*}{$\begin{array}{c}\text { Mezun Olunan } \\
\text { Okul }\end{array}$} & Anadolu & 176 & 76,2 \\
\hline & Erkek & 97 & 42,0 & & Düz Lise & 30 & 13,0 \\
\hline \multirow{3}{*}{ Medeni Hal } & \multirow{2}{*}{ Evli } & \multirow{2}{*}{4} & \multirow{2}{*}{1,7} & & TML & 5 & 2,2 \\
\hline & & & & & Diğer & 19 & 8,2 \\
\hline & Bekâr & 227 & 98,3 & \multirow{3}{*}{ Bölümü Seçme } & \multirow{2}{*}{ İsteyerek } & \multirow{2}{*}{162} & \multirow{2}{*}{70,1} \\
\hline \multirow{5}{*}{ Yaşınız } & \multirow{2}{*}{$17-19$} & \multirow{2}{*}{60} & \multirow{2}{*}{26,0} & & & & \\
\hline & & & & & İstemeyerek & 69 & 29,9 \\
\hline & $20-22$ & 153 & 66,2 & \multirow{3}{*}{$\begin{array}{c}\text { Meslek Hakkında } \\
\text { Bilgi }\end{array}$} & \multirow{2}{*}{ Vardi } & \multirow{2}{*}{165} & \multirow{2}{*}{71,4} \\
\hline & $23-25$ & 10 & 4,3 & & & & \\
\hline & $26+$ & 8 & 3,5 & & Yoktu & 64 & 27,7 \\
\hline \multirow{2}{*}{$\begin{array}{c}\text { Öğretim } \\
\text { Durumunuz }\end{array}$} & Normal & 96 & 41,6 & \multirow{6}{*}{ Gelinen Şehir } & Manisa & 20 & 8,7 \\
\hline & İkinci & 103 & 44,6 & & İstanbul & 18 & 7,8 \\
\hline \multirow{4}{*}{ Sinıfinız } & & & & & İzmir & 18 & 7,8 \\
\hline & 1. Sinıf & 99 & 42,9 & & Afyonkarahisar & 18 & 7,8 \\
\hline & 2. Sinif & 85 & 36,8 & & Aydın & 13 & 5,6 \\
\hline & 3. Sinif & 47 & 20,3 & & Antalya & 12 & 5,2 \\
\hline
\end{tabular}

Tablo 3'de katılımcıların iletişim düzeylerine ilişkin görüşlerinin yüzde, frekans dağılımları ile aritmetik ortalama ve standart sapma değerlerine yer verilmiştir. Tablo 3 'teki bulgulara göre öğrencilerin bilişsel boyuttaki iletişim beceri düzeylerindeki "Karşımdaki kişiyle aynı görüşü paylaşmasam bile fikrine saygı duyarım" ifadesi $(\bar{X}=4,43)$ bu boyuttaki en yüksek ortalamaya sahip ifade olmuştur. Bilişsel boyuttaki en düşük ifade ise, "Karşımdaki kişinin bana ters düşen duygu ve düşüncelerini yargılamaktan kaçınırım" ( $\overline{\mathrm{X}}=3,55)$ olmuştur. Turizm rehberliği öğrencilerinin karşılarındaki kişilerin düşüncelerini önemsedikleri ve buna göre davrandıkları ifade edilebilir.

Duygusal boyuttaki iletişim beceri düzeylerindeki "İletişim kurduğum kimse tarafindan anlaşılmaktan mutluluk duyarım" ifadesi $(\overline{\mathrm{X}}=4,53)$ bu boyuttaki en yüksek ortalamaya sahip ifade olmuştur. Bilişsel boyuttaki en düşük ifade ise, "İnsanlara güvenirim" $(\bar{X}=2,95)$ olmuştur. Turizm rehberliği öğrencilerinin bu boyutta verdikleri cevaplardan anlaşıldığı üzere iletişim kurmaya hevesli oldukları ve karşıda bulunan kişilerle doğru iletişim kurup anlaşıldıklarında bu durumdan hoşnut oldukları söylenebilir.

Davranışsal boyuttaki iletişim beceri düzeylerindeki "Kişilerin, anlatmak istediklerini dinlemek için yeterince zaman ayırırım " ifadesi $(\overline{\mathrm{X}}=4,38)$ bu boyuttaki en yüksek ortalamaya sahip ifade olmuştur. Bilişsel boyuttaki en düşük ifade ise, "Küs olduğum birisiyle barışmak istediğimde ilk adımı atarım (atmaktan çekinmem)" ( $\overline{\mathrm{X}}=3,49)$ olmuştur. Turist rehberliği mesleğinin en önemli özelliklerinden biri de öncelikle karşıdaki kişilerin dinlenmesi gerekliliğidir. Çünkü doğru teşhis koymanın temel anahtarı iyi bir dinleyici olmaktan geçer. "Söz gümüş ise sükut altındır." Atasözü bu durumu en iyi anlatan ifadelerden biridir. 


\section{IIIIII)}

Turist Rehberliği Dergisi (TURED) \& Y1l. 2019, Cilt. 2, Sayı. 1

Journal of Tour Guiding (JOTOG) \& Year. 2019, Volume. 2, Issue. 1

Tablo 3: Katılımcıların İletişim Düzeylerine İlişkin Görüşleri

\begin{tabular}{|c|c|c|c|c|c|c|c|c|c|c|c|c|c|}
\hline \multirow{2}{*}{ 离 } & \multirow{2}{*}{ İfadeler } & \multicolumn{2}{|c|}{$\begin{array}{l}\text { Hiçbir } \\
\text { Zaman }\end{array}$} & \multicolumn{2}{|c|}{ Nadiren } & \multicolumn{2}{|c|}{ Bazen } & \multicolumn{2}{|c|}{ Genellikle } & \multicolumn{2}{|c|}{ Her Zaman } & \multirow[t]{2}{*}{$\bar{X}$} & \multirow[t]{2}{*}{ ss } \\
\hline & & $\mathrm{f}$ & $\%$ & $\mathrm{f}$ & $\%$ & $\mathrm{f}$ & $\%$ & $\mathrm{f}$ & $\%$ & $\mathrm{f}$ & $\%$ & & \\
\hline \multirow{13}{*}{ 氛 } & $\begin{array}{l}\text { İnsanları anlamaya } \\
\text { çalışırım. }\end{array}$ & 4 & 1,7 & 4 & 1,7 & 14 & 6,1 & 82 & 35,5 & 126 & 54,5 & 4,40 & 0,82 \\
\hline & $\begin{array}{l}\text { Düşüncelerimi başkalarına } \\
\text { tam olarak rahatlıkla } \\
\text { iletebilirim (iletmekte } \\
\text { zorluk çekmem). }\end{array}$ & 1 & ,4 & 15 & 6,5 & 43 & 18,6 & 100 & 43,3 & 71 & 30,7 & 3,97 & 0,89 \\
\hline & $\begin{array}{l}\text { Dikkatimi karşımdakinin } \\
\text { ilgi alanı üzerinde } \\
\text { toplayabilirim. }\end{array}$ & 2 & ,9 & 7 & 3,0 & 38 & 16,5 & 101 & 43,7 & 79 & 34,2 & 4,09 & 0,84 \\
\hline & $\begin{array}{l}\text { Eleştirilerimi karşımdaki } \\
\text { kişiyi incitmeden iletirim. }\end{array}$ & 3 & 1,3 & 5 & 2,2 & 47 & 20,3 & 85 & 36,8 & 88 & 38,1 & 4,26 & 2,71 \\
\hline & $\begin{array}{l}\text { Karşımdaki kişiyle aynı } \\
\text { görüşü paylaşmasam bile } \\
\text { fikrine saygı duyarım. }\end{array}$ & - & - & 3 & 1,3 & 21 & 9,1 & 78 & 33,8 & 127 & 55,0 & 4,43 & 0,71 \\
\hline & $\begin{array}{l}\text { Karşımdaki kişinin } \\
\text { konuşmaya ve dinlemeye } \\
\text { istekli olup olmadığını } \\
\text { anlamaya çalışırım. }\end{array}$ & 1 & ,4 & 1 & ,4 & 22 & 9,5 & 83 & 35,9 & 123 & 53,2 & 4,41 & 0,71 \\
\hline & $\begin{array}{l}\text { Dinleyenin anlamaz } \\
\text { göründüğ̈ünde, iletmek } \\
\text { istediklerimi tekrarlar, yeni } \\
\text { kelimelerle ifade eder, } \\
\text { özetlerim. }\end{array}$ & 8 & 3,5 & 15 & 6,5 & 44 & 19,0 & 85 & 36,8 & 78 & 33,8 & 3,91 & 1,04 \\
\hline & $\begin{array}{l}\text { Yanlış tutum ve } \\
\text { davranışlarımı kolaylıkla } \\
\text { kabul ederim. }\end{array}$ & 12 & 5,2 & 19 & 8,2 & 56 & 24,2 & 76 & 32,9 & 65 & 28,1 & 3,71 & 1,12 \\
\hline & $\begin{array}{l}\text { Karşımdaki kişinin bana } \\
\text { ters düşen duygu ve } \\
\text { düşüncelerini yargılamaktan } \\
\text { kaçınırım. }\end{array}$ & 18 & 7,8 & 23 & 10,0 & 52 & 22,5 & 84 & 36,4 & 50 & 21,6 & 3,55 & 1,17 \\
\hline & $\begin{array}{l}\text { İletişim kurduğum kişinin } \\
\text { eğer varsa sorununu } \\
\text { anlamaya çalışırım. }\end{array}$ & 4 & 1,7 & 5 & 2,2 & 18 & 7,8 & 89 & 38,5 & 111 & 48,1 & 4,31 & 0,84 \\
\hline & $\begin{array}{l}\text { Başkaları ile ilişkilerimi } \\
\text { bozacak çıkışlar yapmaktan } \\
\text { kaçınırım. }\end{array}$ & 9 & 3,9 & 11 & 4,8 & 34 & 14,7 & 95 & 41,1 & 78 & 33,8 & 3,97 & 1,02 \\
\hline & $\begin{array}{l}\text { Öneride bulunduğum } \\
\text { kişinin öneriye açık olup } \\
\text { olmadığına dikkat ederim. }\end{array}$ & 5 & 2,2 & 6 & 2,6 & 44 & 19,0 & 88 & 38,1 & 85 & 36,8 & 4,06 & 0,91 \\
\hline & $\begin{array}{l}\text { Kendimi karşımdaki kişinin } \\
\text { yerine koyarak, duygu ve } \\
\text { düşünceleri anlamaya } \\
\text { çalışırım. }\end{array}$ & 2 &, 9 & 5 & 2,2 & 23 & 10,0 & 94 & 40,7 & 103 & 44,6 & 4,28 & 0,80 \\
\hline \multirow{7}{*}{$\begin{array}{l}2 \\
0 \\
0 \\
0 \\
0 \\
0 \\
0 \\
0\end{array}$} & Eleştirilere açığım. & 7 & 3,0 & 10 & 4,3 & 59 & 25,5 & 80 & 34,6 & 71 & 30,7 & 3,87 & 1,00 \\
\hline & $\begin{array}{l}\text { Karşımdaki kişiyi dinlerken } \\
\text { ona odaklanırım. }\end{array}$ & 4 & 1,7 & 2 &, 9 & 26 & 11,3 & 88 & 38,1 & 109 & 47,2 & 4,29 & 0,83 \\
\hline & $\begin{array}{l}\text { İnsanları dinlerken } \\
\text { s1k1lganlık göstermem. }\end{array}$ & 7 & 3,0 & 4 & 1,7 & 45 & 19,5 & 94 & 40,7 & 77 & 33,3 & 4,01 & 0,94 \\
\hline & İnsanlara güvenirim. & 34 & 14,7 & 49 & 21,2 & 68 & 29,4 & 41 & 17,7 & 33 & 14,3 & 2,95 & 1,26 \\
\hline & $\begin{array}{l}\text { Karşı cinsten biriyle iletişim } \\
\text { kurduğumda rahatsızlık } \\
\text { duymam. }\end{array}$ & 7 & 3,0 & 6 & 2,6 & 40 & 17,3 & 69 & 29,9 & 108 & 46,8 & 4,15 & 1,00 \\
\hline & Gerektiğinde özür dilerim. & 4 & 1,7 & 7 & 3,0 & 25 & 10,8 & 72 & 31,2 & 122 & 52,8 & 4,30 & 0,90 \\
\hline & $\begin{array}{l}\text { Çevremdeki insanlara karşı } \\
\text { ilgisizlik göstermem. }\end{array}$ & 5 & 2,2 & 7 & 3,0 & 38 & 16,5 & 91 & 39,4 & 88 & 38,1 & 4,09 & 0,92 \\
\hline
\end{tabular}


Turist Rehberliği Dergisi (TURED) \& Yıl. 2019, Cilt. 2, Sayı. 1

Journal of Tour Guiding (JOTOG) \& Year. 2019, Volume. 2, Issue. 1

\begin{tabular}{|c|c|c|c|c|c|c|c|c|c|c|c|c|c|}
\hline & $\begin{array}{l}\text { Çoğunlukla duygularımdan } \\
\text { eminimdir. }\end{array}$ & 4 & 1,7 & 13 & 5,6 & 48 & 20,8 & 81 & 35,1 & 84 & 36,4 & 3,99 & 0,98 \\
\hline & $\begin{array}{l}\text { İletişim kurduğum kimse } \\
\text { tarafindan anlaş1lmaktan } \\
\text { mutluluk duyarım. }\end{array}$ & 3 & 1,3 & 3 & 1,3 & 11 & 4,8 & 63 & 27,3 & 149 & 64,5 & 4,53 & 0,76 \\
\hline & $\begin{array}{l}\text { Karşımdaki kişiye } \\
\text { güvenmek beni mutlu eder. }\end{array}$ & 6 & 2,6 & 8 & 3,5 & 30 & 13,0 & 64 & 27,7 & 119 & 51,5 & 4,24 & 0,99 \\
\hline & $\begin{array}{l}\text { Her insanı olumlu } \\
\text { beklentilerle karşılarım. }\end{array}$ & 8 & 3,5 & 17 & 7,4 & 55 & 23,8 & 92 & 39,8 & 54 & 23,4 & 3,73 & 1,01 \\
\hline & $\begin{array}{l}\text { İletişim kurduğum } \\
\text { kimselerden, bir şeyler alır } \\
\text { ve onlara da bir şeyler } \\
\text { verdiğimi hissederim. } \\
\end{array}$ & 4 & 1,7 & 5 & 2,2 & 41 & 17,7 & 103 & 44,6 & 76 & 32,9 & 4,05 & 0,86 \\
\hline & $\begin{array}{l}\text { Beni rahatsız eden } \\
\text { duygularımı iletmekte } \\
\text { sıkıntı çekmem. }\end{array}$ & 8 & 3,5 & 10 & 4,3 & 55 & 23,8 & 87 & 37,7 & 68 & 29,4 & 3,86 & 1,00 \\
\hline & $\begin{array}{l}\text { İletişim kurduğum insanlar } \\
\text { tarafindan anlaşıldığımı } \\
\text { hissederim. }\end{array}$ & 5 & 2,2 & 9 & 3,9 & 46 & 19,9 & 105 & 45,5 & 62 & 26,8 & 3,92 & 0,91 \\
\hline \multirow{15}{*}{ 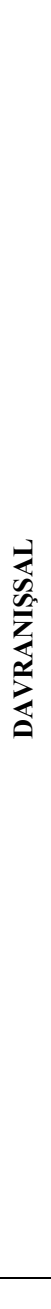 } & $\begin{array}{l}\text { İletişimde bulunduğum } \\
\text { insanlardan gelen öğ̈̈t ve } \\
\text { önerileri içtenlikle dinlerim. }\end{array}$ & 3 & 1,3 & 7 & 3,0 & 38 & 16,5 & 96 & 41,6 & 84 & 36,4 & 4,10 & 0,87 \\
\hline & $\begin{array}{l}\text { Konuşurken, etkili bir göz } \\
\text { iletişimi kurabilirim. }\end{array}$ & 5 & 2,2 & 10 & 4,3 & 21 & 9,1 & 80 & 34,6 & 112 & 48,5 & 4,24 & 0,94 \\
\hline & $\begin{array}{l}\text { Kişilerin, anlatmak } \\
\text { istediklerini dinlemek için } \\
\text { yeterince zaman ayırıım, }\end{array}$ & 4 & 1,7 & 2 & ,9 & 32 & 13,9 & 91 & 39,4 & 96 & 41,6 & 4,38 & 2,77 \\
\hline & $\begin{array}{l}\text { Karşımdaki kişiye } \\
\text { genellikle söz hakkı } \\
\text { veririm. }\end{array}$ & 4 & 1,7 & 3 & 1,3 & 20 & 8,7 & 96 & 41,6 & 103 & 44,6 & 4,28 & 0,82 \\
\hline & $\begin{array}{l}\text { Başkaları konuşurken } \\
\text { sabırsızlanmam, onların } \\
\text { sözünü kesmem. }\end{array}$ & 6 & 2,6 & 3 & 1,3 & 40 & 17,3 & 99 & 42,9 & 78 & 33,8 & 4,06 & 0,90 \\
\hline & $\begin{array}{l}\text { Konuşurken ilk adımı } \\
\text { atmaktan çekinmem. }\end{array}$ & 11 & 4,8 & 14 & 6,1 & 54 & 23,4 & 65 & 28,1 & 84 & 36,4 & 3,86 & 1,12 \\
\hline & $\begin{array}{l}\text { Konuşurken açı, sade ve } \\
\text { düzgün cümleler kurarım. }\end{array}$ & 7 & 3,0 & 9 & 3,9 & 42 & 18,2 & 101 & 43,7 & 68 & 29,4 & 3,94 & 0,95 \\
\hline & $\begin{array}{l}\text { İletişimde bulunduğum } \\
\text { kişinin yüzüne bakarım. }\end{array}$ & 5 & 2,2 & 4 & 1,7 & 27 & 11,7 & 80 & 34,6 & 113 & 48,9 & 4,27 & 0,89 \\
\hline & $\begin{array}{l}\text { Dinlediğim kişiyi daha iyi } \\
\text { anlamak için sorular } \\
\text { yöneltirim. }\end{array}$ & 6 & 2,6 & 4 & 1,7 & 43 & 18,6 & 85 & 36,8 & 90 & 39,0 & 4,09 & 0,94 \\
\hline & $\begin{array}{l}\text { İnsanlarla görüşürken, } \\
\text { bilerek onları rahatlatacak } \\
\text { şeyler yaparım. }\end{array}$ & 6 & 2,6 & 11 & 4,8 & 47 & 20,3 & 97 & 42,0 & 68 & 29,4 & 3,91 & 0,96 \\
\hline & $\begin{array}{l}\text { Dinlerken karşımdaki } \\
\text { kişinin sözünü kesmemeye } \\
\text { özen gösteririm. }\end{array}$ & 5 & 2,2 & 4 & 1,7 & 38 & 16,5 & 90 & 39,0 & 92 & 39,8 & 4,13 & 0,90 \\
\hline & $\begin{array}{l}\text { Küs olduğum birisiyle } \\
\text { barışmak istediğimde ilk } \\
\text { adımı atarım (atmaktan } \\
\text { çekinmem). }\end{array}$ & 24 & 10,4 & 22 & 9,5 & 68 & 29,4 & 49 & 21,2 & 67 & 29,0 & 3,49 & 1,28 \\
\hline & $\begin{array}{l}\text { Ses tonumu konunun } \\
\text { özelliğine göre } \\
\text { ayarlayabilirim. }\end{array}$ & 3 & 1,3 & 13 & 5,6 & 37 & 16,0 & 80 & 34,6 & 95 & 41,1 & 4,10 & 0,95 \\
\hline & $\begin{array}{l}\text { İnsanlara cevaplamada } \\
\text { zorlanacakları ani sorular } \\
\text { yöneltmekten kaçınırım. }\end{array}$ & 13 & 5,6 & 21 & 9,1 & 68 & 29,4 & 81 & 35,1 & 47 & 20,3 & 3,55 & 1,08 \\
\hline & Genel Ortalama & & & & & & & & & & & \begin{tabular}{|l|l|}
, 04 \\
\end{tabular} & $\mathbf{0 , 5 2}$ \\
\hline
\end{tabular}

Turizm rehberliği öğrencilerinin 'insanları anlamaya çalışırım”' ifadesine verdikleri cevapların aritmetik ortalaması diğer ifadelere oranla yüksek $(\bar{X}=4,34)$ çıkmıştır. Söz konusu veriyle ilgili elde edilen bulgular neticesinde turizm öğrencilerinin insanları anlamaya yönelik göstermiş oldukları çabanın fazla olduğu ve sektörün emek yoğun yapısı ve insan ilişkilerinin 
Turist Rehberliği Dergisi (TURED) \& Yıl. 2019, Cilt. 2, Sayı. 1

Journal of Tour Guiding (JOTOG) \& Year. 2019, Volume. 2, Issue. 1

yoğun olduğu düşünüldüğünde elde edilen sonucun sektörde meslek hayatlarına devam etmeyi planlayan öğrenciler için fayda getirici bir unsur olacağ incelendiğinde turizm rehberliği öğrencilerinin iletişim becerileri düzeyinin yüksek olduğu belirlenmiştir. Büyükkuru (2015) tarafından turist rehberlerinin iletişim becerilerini ölçtüğü çalışmada turist rehberlerinin iletişim düzeylerinin $(\bar{X}=4,19)$ yüksek olduğu anlaşılmıştır. Aynı şekilde Pelit ve Karaçor (2015) tarafından yapılan çalışmada turizm öğrencilerinin iletişim becerilerinin genel olarak yüksek olduğu belirlenmiştir. Yapılan araştırmalar ile turizm rehberliği öğrencileri üzerine yapılan bu çalışmanın sonuçları paralellik göstermektedir.

Tablo 4: Öğrencilerin İletişim Düzeylerine İlişkin Yanıtlarının Boyutlar Bazında ve Genel Aritmetik Ortalama Değerleri

\begin{tabular}{|l|c|c|c|}
\hline \multicolumn{1}{|c|}{ Boyutlar } & n & $\overline{\mathrm{X}}$ & Ss. \\
\hline Bilişsel (Zihinzel) İletişim Becerileri & 231 & 4,10 & 0,56 \\
\hline Duygusal (Duyuşsal) İletişim Becerileri & 231 & 4,00 & 0,57 \\
\hline Davranışsal İletişim Becerileri & 231 & 4,03 & 0,63 \\
\hline Genel & 231 & 4,04 & 0,52 \\
\hline
\end{tabular}

Tablo 4'de öğrencilerin iletişim düzeylerine ilişkin yanıtlarının boyutlar bazında ve genel aritmetik ortalama değerleri yer almaktadır. İletişim beceri düzeyleri anket sonuçları incelendiğinde genel olarak turizm rehberliği öğrencilerinin iletişim beceri düzeylerinin yüksek olduğu tespit edilmiştir. Ayrıca boyutlar bazında incelendiğinde elde edilen aritmetik ortalama verilerinin birbirine çok yakın olduğu ve değerlerin yüksek olduğu göze çarpmaktadır. Dolayısıyla turizm rehberliği öğrencilerinin iletişim beceri düzeylerinin yüksek olması, öğrencilerin iletişim beceri düzeyi ile sektör ilişkisinin bilincinde olduğu biçiminde yorumlanabilir. Nitekim turizm rehberliği öğrencilerinin bu farkındalığa sahip olmaları meslek hayatlarında yer edinecekleri işletme açısından bir avantaj oluşturacaktır. Turizm rehberliği öğrencilerinin sahip oldukları iletişim beceri düzeyleri meslek hayatlarında kendilerine güçlü bir referans olacaktır. Öte taraftan turizm rehberliği öğrencilerinin insanlara güven konusunda iletişim sürecinde temkinli davrandıkları elde edilen bulgular arasındadır. Turizm rehberliği öğrencilerinin güven duygusu konusunda temkinli davranmaları iletişim sürecinin sağlıklı bir biçimde yürütülmesi önünde engel oluşturabilir. Katılımcıların dinleme odaklı oldukları ve bunun sonucunda iletişim becerileri konusunda konuşmak kadar dinlemenin etkili bir yön verici olduğunu bilincinde oldukları iletişim beceri düzeylerinin artmasına katkı sağlayan bir diğer etken olarak ifade edilebilir.

Tablo 5'de öğrencilerin iletişim düzeylerine ilişkin yanıtlarının meslek hakkında bilgi sahibi olma durumlarına göre karşılaştırılmasına ilişkin gerçekleştirilen t-testi sonuçları yer almaktadır. Tablo 5 incelendiğinde meslek hakkında bilgi sahibi olma durumuna göre öğrencilerin bilişsel ve davranışsal boyutlarda farklılıklar olduğu ancak, duygusal boyutta herhangi bir farklılık olmadığı sonucuna ulaşılmıştır. Yapılan t-testi analizlerinde, cinsiyetin bilişsel, duygusal ve davranışsal iletişim beceri düzeyleri arasında hiçbir boyutta farklılık olmadığı ortaya çıkmıştır. Pehlivan Baykara, 2005; Erkuş ve Günlü, 2009; Çevik, 2011 tarafindan yapılan çalışmalarda da cinsiyetin iletişim becerilerinde farklılık oluşturmadığı sonuçlarına ulaşılmışıır. Öte yandan Korkut, 1996; Şeker 2000; Durukan ve Maden 2010; Gölönü ve Karc1, 2010; K1lıçoğlu, Gedik ve Akhan 2011; Pelit ve Karaçor, (2015) tarafindan yapılan araştırmalarda ise cinsiyete göre iletişim düzeylerinde farklılık olduğu sonucuna ulaşı1mıştır. 


\section{IIIII)}

Turist Rehberliği Dergisi (TURED) \& Yıl. 2019, Cilt. 2, Sayı. 1

Journal of Tour Guiding (JOTOG) \& Year. 2019, Volume. 2, Issue. 1

Tablo 5: Öğrencilerin İletişim Düzeylerine İlişkin Yanıtlarının Meslek Hakkında Bilgi Sahibi Olma Durumlarına Göre Karşılaştırılması

\begin{tabular}{|c|c|c|c|c|c|c|}
\hline Boyutlar & Meslek Hakkında Bilgi & $\mathbf{n}$ & $\overline{\mathrm{X}}$ & Ss. & $\mathbf{t}$ & $\mathbf{p}$ \\
\hline \multirow{2}{*}{ Bilişsel } & Bilgim vard1. & 164 & 4,16 & 0,55 & \multirow{2}{*}{2,182} & \multirow{2}{*}{$\mathbf{0 , 0 3 0} *$} \\
\hline & Bilgim yoktu. & 64 & 3,98 & 0,55 & & \\
\hline \multirow{2}{*}{ Duygusal } & Bilgim vard1. & 164 & 4,04 & 0,52 & \multirow{2}{*}{1,894} & \multirow{2}{*}{0,060} \\
\hline & Bilgim yoktu. & 64 & 3,89 & 0,63 & & \\
\hline \multirow{2}{*}{ Davranışsal } & Bilgim vard1. & 164 & 4,09 & 0,56 & \multirow{2}{*}{2,460} & \multirow{2}{*}{$0,015^{*}$} \\
\hline & Bilgim yoktu. & 64 & 3,87 & 0,70 & & \\
\hline \multirow{2}{*}{ Genel } & Bilgim vard1. & 164 & 4,10 & 0,49 & \multirow{2}{*}{2,484} & \multirow{2}{*}{$0,014 *$} \\
\hline & Bilgim yoktu. & 64 & 3,91 & 0,53 & & \\
\hline
\end{tabular}

*p $<0,05$

Araştırmada turizm rehberliği öğrencilerinin iletişim beceri düzeylerinin diğer bireysel özelliklerine (medeni hal, öğrenim durumu (normal ve ikinci öğretim), bölümü isteyerek seçme, meslek hakkında bilgi sahibi olma durumu) göre farklılık gösterip göstermediğinin belirlenmesi için gerçekleştirilen t-testi sonucunda; ilgili değişkenler ile öğrencilerin iletişim beceri düzeyleri arasında anlamlı bir farklılık göstermediği belirlenmiştir. Pelit ve Karaçor (2015) tarafından yapılan çalışmanın sonuçlarıyla bu çalışmanın sonuçları benzerlik göstermektedir.

Yapılan varyans analizinden elde edilen bulgularda turizm rehberliği öğrencilerinin konuya ilişkin görüşleri arasında mezun olunan lise türüne göre, sınıf düzeylerine göre ve ikamet edilen yere göre anlamlı fark olmadığı belirlenmiştir. Tutuk, Al ve Doğan (2002), Bingöl ve Demir (2011)'in konuyla ilgili gerçekleştirmiş oldukları çalışmalarında da mezun olunan lise türüne göre öğrencilerin iletişim beceri düzeyleri arasında anlamlı bir farklılık olmadığı sonuçları ortaya çıkmıştır. Benzer şekilde Erigüç, Şener ve Eriş (2013)'in çalışmalarında, öğrencilerin yaş grupları ve devam edilen sınıf ile iletişim beceri düzeyleri arasında herhangi bir farklı1ık olmadığı yönünde bir sonuca ulaşılmıştır. Yine Dilekman, Başçı ve Bektaş (2008) yapmış oldukları araştırmada öğrencilerin sınıf düzeyleri ile iletişim beceri düzeyleri arasında bir farklılık olmadığ 1 sonucuna ulaşılmıştır. Pelit ve Karaçor (2015)'un yapmış oldukları çalışmada da turizm rehberliği öğrencilerinin iletişim beceri düzeyleri ile mezun olunan lise türü, devam edilen sınıf ve ikamet edilen yer (il merkezi vb.) arasında herhangi bir farklılığa rastlanmamıştır. Yapılan bu çalışmalar araştırma sonuçlarıyla paralellik göstermektedir.

Yaş değişkeninin iletişim beceri düzeylerinde farklılık oluşturup oluşturmadığ incelendiğinde yaş gruplarının iletişim becerileri arasında anlamlı bir farklılık oluşturmadığ elde edilen bulgular arasındadır. Öte yandan Razı vd. (2009)'de çalışmalarında 17-19 yaş grubunun diğer yaş gruplarından farklılaştığı ve iletişim becerilerinin daha düşük olduğu yönünde görüş belirtmişlerdir. Kılıçoğlu vd. (2011), Pelit ve Karaçor (2015) çalışmalarında ve bu çalışmada elde edilen sonuçlara benzer sonuçlara ulaşılmıştır.

Araştırmadan elde edilen bulgular genel olarak değerlendirildiğinde, ankete katılım sağlayan öğrencilerin genel olarak iletişim beceri düzeyleri yüksek olarak tespit edilmiştir. Turizm rehberliği öğrencilerinin iletişim beceri düzeylerinin yüksek olması sektörde kariyer yapma isteğinde olan öğrenciler için olumlu bir gelişme olarak nitelendirilebilir. Dolayısıyla turizm rehberliği öğrencilerinin iletişim düzeylerinin yüksek olması turist memnuniyetin sağlanması ve kaliteli hizmetin verilmesi açısından da önem taşımaktadır. Çünkü iletişimin 


\section{IIIII)}

Turist Rehberliği Dergisi (TURED) \& Y1l. 2019, Cilt. 2, Sayı. 1

Journal of Tour Guiding (JOTOG) \& Year. 2019, Volume. 2, Issue. 1

düzeyinin yüksek olması turizm rehberliği öğrencilerinin mesleğe adım attıktan sonra başarılı olabileceklerine dair bir ipucu sunmaktadır.

\section{Sonuç ve Öneriler}

Bu çalışmada Afyon Kocatepe Üniversitesinde lisans düzeyinde eğitim gören turizm rehberliği öğrencilerinin iletişim beceri düzeyleri değerlendirilmiştir. Turizm sektörünün rekabetçi yapısının olması, emek yoğun bir sektör ve mevsimsel özellikler taşımasından dolayı iş gücü devir oranı fazla olan bir sektördür. Dolayısıyla işletmeler daha iyi hizmet verebilmek için işletmeye katkısı daha fazla olan personeli işe almak isteyeceklerdir. Özellikle acentelerde çalışan turist rehberlerinin turizm sezonu boyunca işe çıkma gün sayısının fazla olması birçok yeterlilik ve becerinin yanı sıra iletişim becerilerinin de gelişmiş olmasını gerektirmektedir. Dolayısıyla da turizm rehberliği öğrencilerinin üniversiteden başlamak kaydıyla öğrencilerin iletişim becerilerinin geliştirilmesine katkı sunması da mesleğe başlayacak olan öğrenciler için önemli bir avantaj olacaktır.

Gerçekleştirilen bu araştırmanın bulgularına göre Afyon Kocatepe Üniversitesi'nde lisans düzeyinde eğitim gören turizm rehberliği öğrencilerinin genel olarak "İletişim Becerileri Değerlendirme Ölçeği" puan ortalamalarının yüksek olduğu, iletişim becerisinin meslek hakkında bilgisi olma değişkenine göre anlamlı bir farklılık gösterdiği, diğer değişkenlere bağlı olarak anlamlı bir farklılık göstermediği saptanmıştır. Buradan hareketle çalışma sonucunda elde edilen bulgular bize iletişim kavramının geliştirildiği ölçüde turizm faaliyetlerinin daha sağlam temel üzerine atılacağını göstermiştir. Turizm rehberliği ile iletişim arasındaki ilişki düşünüldügünde; iletişime verilen önemin arttırılması ile rehberlerin tercih edilebilirliği arasında paralel gelişen bir bağlantı olduğu söylenebilir.

Turizm rehberliği öğrencilerinin diğer bireylerle iletişim kurarken kullandıkları iletişim yöntemleri, okuma alışkanlıkları ve kendilerini özgürce ifade etmeleri hem günlük hayatlarında hem de iş hayatlarında onlara yeni rotalar çizecektir. Doğru ve etkili iletişim daha kaliteli çevre ve iş hayatının önünü açacaktır.

Konuyla ilgili olarak öğretim kurumlarına getirilebilecek öneri, turizm sektörü için belirleyici etken olan iletişim kavramı üzerine yapılan çalışmalar arttırılmalı ve öğretim kurumları turizm rehberliği öğrencilerinin iletişim beceri düzeylerini geliştirmeye yönelik müfredat düzenlemeleri yapması, öğrencilerin teorik eğitimden çok pratik uygulamalara ağırlık vermesi, stajlarda öğrencilerin kendilerini daha iyi tanıyabilmesi için uygun ortamların sunulması, topluluk önünde sunum yaptırılması vb. gibi uygulamaların daha ön plana çıkarılması biçiminde ifade edilebilir. Turizm rehberliği öğrencilerinin güncel iletişim becerilerini geliştirmek için gerekli bilimsel kanıtlara dayalı bir eğitim programı hazırlanabilir.

$\mathrm{Bu}$ alanda benzer çalışma yapmak isteyen araştırmacılara verilebilecek öneri ise öğrencilerin iletişim beceri düzeyleri ile farklı değişkenler arasındaki ilişki veya etkilerin neler olduğu konularında araştırmalar gerçekleştirilebilir. Ayrıca özellikle diğer üniversitelerin turizm rehberliği bölümlerinde okuyan öğrencilerin iletişim beceri düzeyleri de araştırılabilir ve üniversitelerdeki rehberlik bölümleri arasında kıyaslama yapılması sağlanabilir. Bununla birlikte, iletişim becerileri ile ilgili sorunlar ortaya konulabilir ve bu sorunlara çözüm önerileri getirilebilir. Aynı zamanda iletişim becerileri ile alakalı olarak ilgili kurum ve kuruluşlara gelecekte yapılacak/yapılması düşünülen çalışmalara bu çalışmanın sonuçları fikir verebilir. 


\section{Kaynakça}

Alshatnawi, A. R. (2014). Assessing Communication Skills among Jordanian Tour Guides: German Tourists Perceptions, Journal of Management Research, 6(1), 1-11. http://dx.doi.org/10.5296/jmr.v6i1.4361.

Bingöl, G., Demir, A.,(2011). Amasya Sağlık Yüksekokulu Öğrencilerinin İletişim Becerileri, Göztepe Tip Dergisi, 26 (4), 152-159.

Büyükkuru, M. (2015). Turist Rehberlerinin İletişim Becerilerinin Turistlerin Tur Deneyimi Üzerine Etkisi: Nevşehir Illinde Bir Araştırma, Yayınlanmamış Yüksek Lisans Tezi, Nevşehir: Nevşehir Hacı Bektaş Veli Üniversitesi, Sosyal Bilimler Enstitüsü.

Çevik, D. B. (2011). Müzik öğretmeni adaylarının iletişim becerileri, Gazi Üniversitesi Eğitim Fakültesi Dergisi, 31, 1-13.

Dilekman, M., Başçı, Z., Bektaş, F., (2008). Eğitim Fakültesi Öğrencilerinin İletişim Becerisi, Atatürk Üniversitesi Sosyal Bilimler Enstitüsü Dergisi, 12(2), 223-231.

Durukan, E. ve Maden, S., (2010). Türkçe Öğretmenlerinin İletişim Becerileri Üzerine Bir Araştırma, Sosyal Bilimler Araştırmaları Dergisi, 1, 59-74.

Erigüç, G. ve Şener, T., Eriş, H., (2013). İletişim Becerilerinin Değerlendirilmesi: Bir Meslek Yüksekokulu Örneği, Hacettepe Sağllk İdaresi Dergisi, 16 (1), 45-65.

Erkuş, A. ve Günlü, E. (2009). İletişim Tarzının ve Sözsüz İletişim Düzeyinin Çalışanların İş Performansına Etkisi: Beş Yıldızlı Otel İşletmelerinde Bir Araştırma, Anatolia: Turizm Araştırmaları Dergisi, 20(1), 7-24.

Ersanl1, K. ve Balc1, S. (1998). İletişim Becerileri Envanterinin Geliştirilmesi: Geçerlik ve Güvenirlik Çalışması, Türk Psikolojik Danışma ve Rehberlik Dergisi, 2(10).

Gaskar, S. ve Özyazıcıŏ̆lu, N., (2014). Anadolu Sağlık Meslek Lisesi Öğrencilerinin İletişim Becerileri, The Journal of Current Pediatrics, 1, 20-25.

Gölönü, S., Karc1, Y., (2010). İletișim Meslek Lisesi Öğrencilerinin İletişim Beceri Düzeylerinin İncelenmesi (Ankara İl Örneği), Gazi Üniversitesi İletişim Fakültesi İletişsim Kuram ve Araştırma Dergisi, 31, 123-140.

Hosseyni, S. S. (2012). The Role of Nonverbal Communication Skills in Guiding Tourists, Global Advanced Research, Journal of Management and Business Studies, 1(8), 253-258.

Kılıçoğlu, G., Gedik, H., Akhan, N. E., (2011). Sosyal Bilgiler Öğretmen Adaylarının İletişim Becerilerinin Değerlendirilmesi, 2nd International Conference on New Trends in Education and Their Implications, 27-29 Nisan 2011, Antalya, 1243-1251.

Korkut, F. (1996). Lise Öğrencilerinin Bazı Değişkenler Açısından İletişim Becerilerinin Değerlendirmeleri, III. Ulusal Psikolojik Danışma ve Rehberlik Kongresi, Çukurova Üniversitesi, Adana.

Kunnan, A. J. (1998). An Iintroduction to Structural Equation Modelling for Language Assessment Research. Language Testing, 15(3), 295-332.

Mısırl1, İ. (2010). Genel ve Teknik Illetişim Kavramlar İlkeler Uygulamalar (5. Baskı). Ankara: Detay Yayıncilık.

Pehlivan Baykara, K. (2005). Öğretmen Adaylarının İletişim Becerisi Algıları Üzerine Bir Çalışma, Illköğretim-online, 4, 17-23.

Pelit, E. ve Karaçor, M. (2015). Turizm Öğrencilerinin İletişim Becerileri Üzerine Bir Araştırma: Afyon Kocatepe Üniversitesi Örneği, Gaziantep Üniversitesi Sosyal Bilimler Dergisi, 14 (4), 847-872. DOI: 10.21547/jss.256748.

Pond K. L. (1993). The Professional Guide: Dynamic of Tour Guiding, Van Nostrand Reinhold, New York.

Razı, G. S., Kuzu, A., Yıldız, A. N., Ocakçı, A. F., Arifoğlu, B. C. (2009). Çalışan Gençlerde Benlik Saygısı, İletişim Becerileri ve Stresle Baş Etme, TAF Preventive Medicine Bulletin, $8(1), 17-26$. 
Turist Rehberliği Dergisi (TURED) \& Yıl. 2019, Cilt. 2, Sayı. 1

Journal of Tour Guiding (JOTOG) \& Year. 2019, Volume. 2, Issue. 1

Shiel, G., \& Cartwright, F. (2015). Analyzing Data from a National Assessment of Educational Achievement (Volume 4). Washington: International Bank for Reconstruction and Development / The World Bank.

Şeker, A. (2000). "Sınıf Öğretmenlerinin İletişim Becerileri ile Sınıf Atmosferi Arasındaki İlişkinin Çeşitli Değişkenler Açısından İncelenmesi”. Yayınlanmamış Yüksek Lisans Tezi, Konya: Selçuk Üniversitesi, Sosyal Bilimler Enstitüsü.

Tabachnick, B. G., \& Fidell, L. S. (2013). Using Multivariate Statistics (Sixth Edition). United States of America: Pearson.

Tetik, N. (2006). "Türkiye'de Profesyonel Turist Rehberliği ve Müşterilerin Turist Rehberlerinde Beklentilerinin Analizi (Kuşadası Örneği)". Yayınlanmamıș Yüksek Lisans Tezi, Balıkesir: Balıkesir Üniversitesi, Sosyal Bilimler Enstitüsü.

Tutuk, A., Al, D. ve Doğan, S. (2002). Hemşirelik Öğrencilerinin İletişim Becerisi ve Empati Düzeylerinin Belirlenmesi, Cumhuriyet Üniversitesi Hemşirelik Yüksek Okulu Dergisi, 6, 36-41. 